\title{
Pengaruh Strategi Student Fasilitator And Explaining (SFE) Terhadap Hasil Belajar Peserta Didik Di Masa Pandemi Covid-19
}

\author{
Nur Laily Qomariyah, Akhmad Fauzi \\ Program Studi Pendidikan Guru Madrasah Ibtidaiyah, IKHAC Mojokerto
}

\begin{abstract}
Abstrak
Salah satu upaya peningkatan hasil belajar peserta didik dapat dilakukan melalui proses pembelajaran yang aktif dan kreatif semisal menggunakan strategi Student Fasilitator and Explaining (SFE). Penelitian ini bertujuan untuk mengetahui keterlaksanaan pembelajaran dan mengetahui pengaruh strategi SFE dalam pembelajaran daring terhadap hasil belajar peserta didik pada tema 8 subtema 3 dengan menggunakan pendekatan kuantitatif, desain penelitian One Group Pretest-Posttest. Pembelajaran dengan startegi SFE ini dilakukan secara online mengingat sekolah belum melakukan tatap muka di masa pandemi ini. Teknik pengumpulan data menggunakan instrumen observasi, penilaian keterlaksanaan pembelajaran, dan berupa instrumen soal Pretest-Posttest. Hasil penelitian menunjukkan nilai rata-rata observasi sebesar 86,66 termasuk dalam kriteria sangat baik. Hasil belajar siswa menunjukkan jumlah siswa yang mencapai ketuntasan meningkat dari $14,3 \%$ menjadi $85,7 \%$ setelah pembelajaran dengan strategi SFE. Kesimpulan pada penelitian ini adalah pembelajaran menggunakan strategi SFE dalam pembelajaran daring pada tema 8 subtema 3 terlaksana dengan sangat baik berpengaruh terhadap peningkatan hasil belajar peserta didik kelas IV di MI Darussalam Pacet.
\end{abstract}

Kata kunci: Strategi Student Fasilitator and Explaining (SFE); Hasil Belajar;

\section{Pendahuluan}

Pendidikan menurut UU No 20 Tahun 2003 adalah usaha sadar dan terencana untuk mewujudkan suasana belajar dan proses pembelajaran supaya peserta didik secara 
aktif dapat mengembangkan potensi dirinya untuk memiliki kekuatan spiritual keagamaan, pengendalian diri (emosional), kepribadian, kecerdasan, akhlak mulia, serta keterampilan yang diperlukan dirinya, masyarakat, bangsa dan negara. Manusia yang berkualitas dan berpotensi dapat dibentuk dengan waktu yang tidak cepat dan harus melalui proses belajar terlebih dahulu.

Belajar adalah suatu aktivitas mental dan psikis yang berlangsung dalam interaksi dengan lingkungan yang menghasilkan sejumlah perubahan dalam pengetahuanpemahaman, keterampilan dan nilai sikap (Triwiyanto, 2015). Keberhasilan semua itu dapat dicapai dengan melalui metode pembelajaran yang sesuai dari tujuan pembelajaran itu sendiri. Berdasarkan hasil observasi dilapangan, hasil belajar peserta didik menunjukkan ketuntasan belajar peserta didik kelas IV kurang dari yang diharapkan. Salah satu penyebab peserta didik belum mampu mencapai KKM (Kriteria Ketuntasan Minimal) adalah metode pembelajaran yang digunakan oleh guru saat kegiatan belajar mengajar masih cenderung berpusat pada guru (teacher centre) bukan berpusat kepada peserta didik (student centre). Sehingga inspirasi, rangsangan kreatifitas dan literasi yang didapatkan oleh peserta didik tidak terasah dengan maksimal. Selain itu, pemahaman materi yang diserap oleh peserta didik hanya sebatas mendengar dan menulis sehingga proses pembelajaran tersebut tidak menciptakan proses pembelajarann yang aktif dan kreatif. Selain itu, kekreatifitasan guru dalam penggunaan metode dan juga strategi pembelajaran kurang variatif. Hal ini mengakibatkan kurangnya semangat peserta didik dan kurang aktifnya mereka dalam mengikuti kegiatan pembelajaran sehingga berpengaruh terhadap hasil belajar peserta didik.

Berbagai macam strategi dalam kegiatan belajar mengajar yang dapat digunakan oleh seorang guru agar peserta didik dapat lebih aktif dan kreatifitas, literasi juga inspirasinya dapat terasah lebih maksimal serta materi yang didapat tidak hanya mendengar dan menulis saja diantaranya adalah melalui penggunaan strategi Student Fasilitator and Explaining (SFE). Strategi pembelajaran Student Fasilitator and Explaining (SFE) dapat meningkatkan kreatifitas dan prestasi belajar peserta didik (Suprijono, 2012). Strategi student facilitator and explaining (SFE) dapat membantu tercapainya pembelajaran yang tidak hanya berpusat pada guru (teacher centre), namun juga memberikan kesempatan bagi peserta didik untuk lebih aktif dalam mengikuti pembelajaran, Serta memberikan perubahan yang positif dalam hasil belajar peserta didik.

Strategi Student Facilitator and Explaining (SFE) merupakan pembelajaran aktif, inovatif, kreatif, efektif dan menyenangkan dengan cara membantu peserta didik untuk membangun ketertarikan antara informasi (pengetahuan) baru dengan pengalaman yang telah dimiliki dan dikuasai peserta didik, selanjutnya peserta didik diajarkan bagaimana mereka mempelajari konsep dan bagaimana konsep tersebut dapat dipergunakan (Khotim, 2019). Melalui strategi Student Facilitator and 
Explaining (SFE) peserta didik mendapat kesempatan untuk berperan sebagai seorang pengajar yang menjelaskan materi dan memfasilitasi proses pembelajaran karena strategi ini merupakan suatu pembelajaran bagi siswa untuk mempresentasikan ide, gagasan dan pendapatnya sendiri.

Strategi Student Facilitator and Explaining (SFE) juga memungkinkan untuk meningkatkan motivasi peserta didik dalam mengikuti proses pembelajaran sehingga hasil belajar peserta didik dapat meningkat daripada menggunakan metode sebelumnya. Berdasarkan uraian diatas, upaya yang dapat dilakukan oleh peneliti guna meningkatkan hasil belajar peserta didik adalah melakukan penelitian yang berjudul "Pengaruh Strategi Student Fasilitator and Explaining (SFE) terhadap Hasil Belajar Peserta Didik Kelas IV dalam Pembelajaran Daring pada Tema 8 Subtema 3 di MI Darussalam Pacet”.

\section{Metodologi}

Pada penelitian ini, peneliti menggunakan pendekatan kuantitatif dengan desain penelitian One Group Pretest-Postest Design dimana sebelum diberi perlakuan, terlebih dahulu diadakan Pretest, dengan demikian hasil perlakuan yang didapat lebih akurat dengan memandingkan hasil sebelum perlakuan dengan sesudah perlakuan. Penelitian dilaksanakan di kelas IV-A MI Darussalam, Pacet-Mojokerto.

Teknik pengumpulan data melalui observasi dan tes hasil belajar. Observasi yang digunakan peneliti adalah jenis observasi partisipasi dimana peneliti ikut terlibat langsung dan ikut melakukan apa yang dikerjakan oleh sumber data sekaligus mengamati aktifitas peserta didik dan aktifitas peneliti bagi observer. Sedangkan data yang diperoleh dari observasi selanjutnya dianalisis deskriptif untuk mengetahui keterlaksanaan pembelajaran dengan strategi SFE. Tes hasil belajar dilakukan untuk mengukur sejauh mana peserta didik menguasai materi yang telah diajarkan oleh guru melalui pretest sebelum pembelajaran SFE dan postest setelah pembelajaran SFE. Masing-masing pretest dan postest dihitung rata-ratanya untuk mengetahui adanya peningkatan atau tidak hasil belajar siswa.

\section{Hasil dan Pembahasan}

Keterlaksanaan pembelajaran menggunakan strategi Student Fasilitator and Explainning (SFE) secara daring diketahui melalui observasi yang dilakukan oleh Wali kelas kelas IV ketika peneliti melaksanakan kegiatan pembelajaran. Sebagai acuan penilaian, observer menggunakan lembar observasi penilaian keterlaksanaan pembelajaran yang memuat sintaks tahapan strategi pembelajaran SFE yang telah disediakan oleh peneliti. Diketahui bahwa semua item sintaks pembelajaran Student 
Fasilitator and Explaining (SFE) terlaksana namun tiap item memperoleh skor penilaian yang berbeda. Adapun perhitungan skornya adalah sebagai berikut:

$$
\begin{aligned}
& \text { Nilai Observasi }=\frac{\text { skor perolehan }}{\text { skor maksimal }} \times 100 \\
& \begin{aligned}
& \ldots \ldots \ldots \ldots \ldots \ldots \ldots \ldots \ldots \ldots \ldots \ldots \ldots \ldots \ldots \ldots \ldots \ldots \ldots \ldots \ldots \\
& \text { Nilai Observasi }=\frac{26}{30} \times 100 \\
&=86,66
\end{aligned}
\end{aligned}
$$

Berdasarkan hasil perhitungan dengan rumus diatas, nilai observasi yang didapatkan sebesar 86,66 yang berarti bahwa keterlaksanaan pembelajaran menggunakan strategi Student Fasilitator and Explaining (SFE) di kelas IV dalam pembelajaran daring pada Tema 8 Subtema 3 MI Darussalam sangat baik.

Peserta didik sangat antusias dalam mengikuti pembelajaran. Langkah pertama pembelajaran adalah peneliti mengirimkan video pembelajaran dimana video tersebut berisi kompetensi yang harus dicapai, dan menjelaskan garis besar materi yang disertai dengan demonstrasi. Pentingnya menyampaikan kualifikasi yang akan dipelajari kepada peserta didik adalah agar mengetahui fokus materi yang harus dikuasai. Kemudian penyampaian materi secara garis besar melalui demonstrasi bertujuan untuk memancing fokus peserta didik untuk menganalisa informasi yang didapat dan menemukan konsep dari materi yang sedang dipelajari. Selanjutnya, peneliti memberikan kesempatan kepada peserta didik untuk membuat bagan atau peta konsep terkait materi yang dipelajari. Sesuai dengan teori perkembangan Piaget, Perkembangan kognitif yang sedang dilalui peserta didik kelas IV adalah tahap operasional konkrit artinya pada tahap ini telah memahami operasi logis dengan bantuan benda konkrit hal ini sesuai dengan tahapan pembelajaran ini, setelah memahami materi melalui demonstrasi peserta didik mengkontruksikan pemahaman tentang materi yang didapatkan melalui peta konsep.

Peserta didik mengirimkan foto bagan atau peta konsep yang telah dibuat kemudian menjelaskan maksud peta konsep tersebut melalui voice note kepada peneliti sebagai syarat kehadiran. Hal ini bertujuan untuk melatih mental peserta didik agar berani menyampaikan argumentasi atas apa yang diketahui dan dianggap benar. Antusiasme peserta didik terlihat ketika menjelaskan peta konsep yang disusun, proses penyusunan peta konsep yang dilakukan tentunya melalui membaca materi dari berbagai sumber belajar, hal ini merupakan proses berpikir mereka. Menurut Piaget, seorang anak berfikir sepanjang ia berbuat, tanpa berbuat berarti anak itu tidak berfikir (Nasikh, 2015). Sehinggga ketika peserta didik membaca materi, menyusunan peta konsep hingga menjelaskan kembali peta konsep yang telah disusun berarti pada aktivitas tersebut peserta didik telah melakukan proses berfikir. 
Pada akhir pembelajaran setelah semua peserta didik mengirimkan bagan atau peta konsep, peneliti menerangkan kembali materi secara keseluruhan sekaligus menyimpulkan beberapa pendapat dari peserta didik yang bertujuan agar tidak terdapat miskonsepsi dan menepis kesalahan peserta didik dalam mengintrepetasikan materi. Kemudian kegiatan pembelajaran ditutup dengan memberikan apresiasi sekaligus memberikan motivasi kepada peserta didik agar tetap semangat dalam mengikuti proses pembelajaran.

Berdasarkan hasil observasi yang dilakukan oleh guru wali kelas kelas IV, peneliti telah melaksanakan langkah-langkah pembelajaran dengan sangat baik. Hal ini dibuktikan dengan skor total yang didapat sebesar 26 dimana skor maksimalnya adalah 30 kemudian diolah menggunakan rumus sehingga didapatkan nilai rata-rata sebesar 86,7\%. Dari hasil perhitungan tersebut, keterlaksanaan pembelajaran menggunakan strategi Student Fasilitator and Explaining (SFE) di kelas IV dalam pembelajaran daring pada Tema 8 Subtema 3 MI Darussalam termasuk dalam kriteria sangat baik.

Penerapan strategi Student Fasilitator and Explainning (SFE) bertujuan untuk mengetahui perbedaan rata-rata hasil belajar peserta didik sebelum diberikan perlakuan atau pre-test dan sesudah diberikan perlakuan yaitu post-test. Diketahui hasil pretest menunjukkan 18 dari 21 peserta didik yang tidak tuntas dengan perolehan nilai dibawah KKM dan 3 dari 21 peserta didik yang telah memenuhi KKM atau dianggap tuntas yakni $14,3 \%$, kemudian mengalami peningkatan setelah diterapkan strategi SFE dalam proses pembelajaran yaitu yang semula 3 menjadi 18 peserta didik atau $85,7 \%$ dari total keseluruhan dengan nilai memenuhi Kriteria dan dikatakan telah tuntas. Berdasarkan hasil analisis jumlah sampel sebanyak 21 siswa dengan nilai minimum pre-test sebesar 42,50 nilai maksimum sebesar 80,00 kemudian didapatkan nilai rata-rata 64,4048 . Sedangkan nilai minimum post-test sebesar 70,00 nilai maksimum 92,50 dan nilai rata-rata sebesar 83,8810.

Pada penelitian ini, keterlaksanaan pembelajaran menggunakan strategi Student Fasilitator and Explaining (SFE) sangat baik menjadi salah satu solusi untuk mendukung meningkatnya hasil belajar peserta didik. Penerapan strategi ini menciptakan suasana belajar yang mengesankan dan bermakna dalam pembelajaran karena pada prosesnya peserta didik menyusun peta konsep yang mana penyusunan tersebut tentunya melalui membaca materi yang merupakan proses berfikirnya sehingga pemahaman dan daya ingat terhadap materi akan meningkat. Selain itu strategi SFE ini juga melatih keberanian peserta didik untuk menjelaskan peta konsep yang telah disusun. Begitu pula peningkatan hasil belajar peserta didik kelas IV pada Tema 8 subtema 3 dalam penelitian ini didukung dengan penerapan strategi Student Fasilitator and Explaining (SFE) dalam proses pembelajaran yang terlaksana dengan sangat baik. Hasil belajar peserta didik sebelum diterapkan strategi SFE hanya 14,3\% yang tuntas namun mengalami peningkatan setelah penerapan strategi SFE yakni menjadi $85,7 \%$ peserta didik dengan perolehan nilai yang telah memenuhi kriteria 
ketuntasan. Adapun 14,3\% peserta didik belum mencapai nilai KKM setelah diterapkannya strategi SFE berdasarkan analisa peneliti adalah berasal dari berbagai faktor seperti kurangnya pendampingan dan arahan dari orang tua ketika pembelajaran berlangsung, kondisi fisik yang kurang prima, dan minat anak untuk mengikuti kegiatan pembelajaran secara daring.

\section{$4 \quad$ Kesimpulan}

Berdasarkan hasil penelitian dan pembahasan, maka kesimpulan pada penelitian ini adalah strategi Student Fasilitator and Explaining (SFE) dapat meningkatkan hasil belajar peserta didik di kelas IV melalui pembelajaran secara online, di dukung keterlaksanaan pembelajaran yang dilakukan juga sangat baik.

\section{Daftar Pustaka}

Huda, Miftakhul. 2013. Model-Model Pengajaran dan Pembelajaran,Isu-Isu Metodis dan Pragmatis. Yogyakarta: PUSTAKA PELAJAR

Khotim, Syafi'ah Nur. 2019. Modul Strategi Pembelajaran. Yogyakarta: BENING PUSTAKA

Suprijono, 2012. Cooperative Learning: Teori dan Aplikasi Paikem,(Yogyakarta:Pustaka Belajar,2012)

Suprijono, 2017. Pengertian Metode Pembelajaran Student Fasilitator and Explaining”. fatkhan.web.id/pengertian-metode-pembelajaran-studentfasilitator-and-explaining/diakses pada 11 januari 2021 pukul 10:45

Triwiyanto, Teguh. 201. pengantar pendidikan. Jakarta: BUMI AKSARA

Djali. Muldjono, Pudji. Pengukuran Dalam Bidang Pendidikan. Jakarta: Grasindo. 2008.

Prastowo, Andi. Panduan Kreatif Membuat Bahan Ajar Inovatif. Yogyakarta: DIVA Press. 2015.

Sudijono, Anas. Pengantar Statistika. Jakarta: Rajawali Press. 2007.

Sugiyono. Metode Penelitian Kuantitatif, Kualitatif, dan R\&D. Bandung: Alfabeta. 2011. 
Trianto, Model Pembelajaran Terpadu: Konsep, Strategi, dan Implementasinya dalam Kurikulum Tingkat Satuan Pendidikan, (Jakarta: Bumi Aksara, 2010), 111.

Umar, Husein. Metode Riset Bisnis. Jakarta: Gramedia Pustaka Utama. 2013.

Widyoko, Eko Putro. Evaluasi Program Pembelajaran. Yogyakarta: Pustaka Pelajar. 2009. 